\title{
The effect of low frequency noise on the behaviour of juvenile Sparus aurata ${ }^{\text {a) }}$
}

Manuela Mauro, ${ }^{1}$ Isabel Pérez-Arjona, ${ }^{2, b)}$ Eduardo J. Belda Perez, ${ }^{2, b)}$ Maria Ceraulo, ${ }^{3, c)}$ Manuel Bou-Cabo, ${ }^{4, b)}$ Thomas Benson, ${ }^{5}$ Victor Espinosa, ${ }^{2}$ Francesco Beltrame, ${ }^{6}$ Salvatore Mazzola, ${ }^{3}$ Mirella Vazzana, ${ }^{1}$ and Giuseppa Buscaino ${ }^{3}$

${ }^{1}$ Department of Biological, Chemical and Pharmaceutical Sciences and Technologies (STEBICEF), University of Palermo, Via Archirafi 18, Palermo, 90123, Italy

${ }^{2}$ Universitat Politècnica de València, Campus de Gandia, C/Paranimf, 1-46730, Spain

${ }^{3}$ BioacousticsLab, National Research Council UOS of Capo Granitola, Via del mare, Torretta Granitola, 3-91021, Italy

${ }^{4}$ Instituto Español de Oceanografía (IEO), C. O. Murcia, San Pedro del Pinatar (Murcia), 1-30740, Spain

${ }^{5}$ HR Wallingford, Howbery Park, Wallingford, OX10 8BA, United Kingdom

${ }^{6}$ ENR, The Italian Institution for Research and Promotion of Standardization, Via Francesco Crispi, Palermo, 248-90139, Italy

\begin{abstract}
:
Anthropogenic activities are causing increased noise levels in the marine environment. To date, few studies have been undertaken to investigate the effects of different noise frequencies on the behaviour of juvenile fish. In this study, the behavioural changes of juvenile gilthead seabream (Sparus aurata) are evaluated when exposed to white noise filtered in third-octave bands centred at $63,125,500$, and $1000 \mathrm{~Hz}$ (sound pressure level, 140-150 dB re $1 \mu \mathrm{Pa}$ ) for $7 \mathrm{~h}$. The group dispersion, motility, and swimming height of the fish were analysed before and during the acoustic emission. Dispersion of the fish was found to reduce immediately upon application of low frequency sound (63 and $125 \mathrm{~Hz}$ ) with a return to control condition after $2 \mathrm{~h}$ (indicative of habituation), whereas at $1 \mathrm{kHz}$, dispersion increased after $2 \mathrm{~h}$ without any habituation. The motility decreased significantly at $63 \mathrm{~Hz}$ throughout the $7 \mathrm{~h}$ of sound exposure. The swimming height decreased significantly for all frequencies other than $125 \mathrm{~Hz}$. The results of this study highlight significant variations in the behavioural responses of juvenile fish that could have consequences on their fitness and survival. (C) 2020 Acoustical Society of America. https://doi.org/10.1121/10.0001255
\end{abstract}

(Received 9 November 2019; revised 27 April 2020; accepted 27 April 2020; published online 9 June 2020)

[Editor: Joseph A. Sisneros]

Pages: 3795-3807

\section{INTRODUCTION}

Different types of human activities, such as freight shipping, seismic surveying, sonar usage and pleasure boating, are causing an increase in underwater noise in marine ecosystems (Hawkins et al., 2015; Slabbekoorn et al., 2010). In recent years anthropogenic activity and, therefore, noise levels have increased in these ecosystems, and for this reason it is considered a pollutant by the World Health Organization (Kunc et al., 2016), the International Maritime Organization, and the Marine Strategy Framework Directive (MSFD) of the European Union (2017/56/EC). The MSFD promotes the achievement of a good quality environmental status for European waters by 2020 and, in particular, the descriptor 11.2 on "continuous low frequency sound" aims to monitor trends in the ambient noise level within the third-octave bands of 63 and $125 \mathrm{~Hz}$ (centre frequencies). Although several scientific works highlight the importance of understanding better the effects of this new pollutant on

\footnotetext{
a) This paper is part of a special issue on The Effects of Noise on Aquatic Life.

b) Also at: Unidad Mixta de Investigación IEO-UPV, Tinglados Muelle Frutero, Grau de Gandia, 46370, Spain.

${ }^{c)}$ Electronic mail: ceraulo.maria@gmail.com. ORCID:0000-0003-2140-1367.
}

individuals, on populations, and therefore on whole ecosystems (Borsani et al., 2015), important information about biological and behavioural responses of fish and invertebrates still remain unknown (Hawkins et al., 2015). Several studies have shown that anthropogenic sound can affect marine life at physical, physiological, and behavioural levels (Slabbekoorn et al., 2010; Carroll et al., 2017). Physical and physiological effects have been observed in the larval stages of some invertebrate and fish species with increases in mortality rates and developmental delays (Nedelec et al., 2014; Nedelec et al., 2015; McCauley et al., 2017; Fakan et al., 2019); while adults of invertebrates, fish, and mammals show evidence of damage to the auditory system (Solé et al., 2013a; Solé et al., 2013b; Ketten et al., 1993; McCauley et al., 2003). Effects were also found in serum and tissue biochemical parameters for invertebrate and fish species with significant increases in the levels of protein concentration, glucose, Heat Shock Proteins (HSPs) expression, and enzymatic activity (Buscaino et al., 2010; Celi et al., 2016; Vazzana et al., 2016, 2017, 2020a,b). Marine mammals showed significant changes in heart rate levels (Lyamin et al., 2011) and hormonal levels (glucocorticoids, norepinephrine, epinephrine, and dopamine; Romano et al., 2004; Rolland et al., 2012). In addition to the physical and 
physiological effects, it has been shown that anthropogenic sounds can also influence the behavioural responses of marine organisms with potentially negative effects even on their survival. At the larval stage of some invertebrate and fish species, exposure to anthropogenic sounds has been associated with a reduction in settlement behaviour and, therefore, the probability of finding a suitable substrate for development (Simpson et al., 2010; Holles et al., 2013; Lecchini et al., 2018). For adults, anthropogenic sound has been linked with (i) increases in locomotion activities (Buscaino et al., 2010; MuellerBlenkle et al., 2010; Filiciotto et al., 2014; Zhou et al., 2018); (ii) a reduction in prey-predator interactions and, therefore, in defence or attack capabilities (Day et al., 2016; Simpson et al., 2016); (iii) a reduction in foraging activities and, therefore, in growth rates (Shi et al., 2019; Nedelec et al., 2017); and (iv) increases in startle responses (McCauley et al., 2000; Nedelec et al., 2015). It has also been observed that anthropogenic emissions can (a) reduce the communication skills of fish and mammals (Vasconcelos et al., 2007; Gordon et al., 2003; Codarin et al., 2009; Slabbekoorn et al., 2010), (b) cause movement away from the acoustic source and reduce reproductive capacity (Mueller-Blenkle et al., 2010; Castellote et al., 2012), and (c) increase swimming depth and reduce group cohesion (Van Parijs and Corkeron, 2001; Cox et al., 2006; Sarà et al., 2007; Neo et al., 2015; Martín López, 2015; De Quirós et al., 2019). Focusing, in particular, on behavioural responses of fish described in the literature, there are many studies on adults and larvae, whereas impacts of noise on the behaviour of juveniles have not yet been fully investigated (Spiga et al., 2017; Holmes et al., 2017; Ferrari et al., 2018; Zhou et al., 2018).

According to several authors, adult fish are more sensitive and vulnerable to acoustic stress than juveniles due to the larger size of the swim bladder (Casper et al., 2013). However, other works claim that the bladder effects diminish in larger fish due to the greater distance between the swim bladder and the otoliths (Salas et al., 2019). Indeed, recent studies highlighted that swim bladders can serve to dampen vibrations, avoiding the resonance effects by means of a particular viscoelastic structure (Fine et al., 2016; Parmentier and Fine, 2016).

For juvenile individuals, stress can be particularly harmful as it can negatively affect growth (McCormick et al., 1998; Woodley and Peterson, 2003) and increase the risk of predation (Sogard, 1997). Moreover, Salas et al. (2019) showed in the red drum that changes in bladder morphology and otolith-bladder relationships during larval stages can influence auditory capacity. Thus, in general, changes that occur during the early life stages of some fish species can result in dramatic changes in their structure, physiology, and behaviour. Furthermore, any stress that changes their sensory information can negatively affect their ability to assess risk and select appropriate reactions. This could make them more vulnerable to predators by influencing their survival (Mesa, 1994; McCormick et al., 2002; Nilsson et al., 2007; Munday et al., 2010; McCormick and Lönnstedt, 2013) and the future generations.
Numerous studies have analysed the effects of specific acoustic emissions (natural or synthetic) on marine organisms, but few have examined the effects of different frequencies on groups of individuals of the same species. Since there are few studies on juvenile fish and, to our knowledge, there are none comparing the effects of different acoustic frequencies on their behaviour, we studied the stress effects of four different low frequency bands (third-octave centred at $63 \mathrm{~Hz}, 125 \mathrm{~Hz}, 500 \mathrm{~Hz}$, and $1000 \mathrm{~Hz}$ ) on juvenile gilthead seabream (Sparus aurata, Linnaeus, 1758). This is an important commercial demersal fish species which lives in small groups at a depth range from 1 to $30 \mathrm{~m}$ (Lloris, 2005). We analysed the effects of noise on dispersion, motility, and swimming height of the group. The aims of our work were to contribute a better understanding of the effects of the acoustic stress of maritime activities on juvenile individuals of a commercially important fish species, identifying which frequencies have the greatest impact on them and whether they habituate to the sound.

\section{MATERIALS AND METHODS}

\section{A. Experimental animals}

The experiments were carried out at the Polytechnic University of Valencia (UPV, Gandia Campus, Spain). In total, 90 juveniles of $S$. aurata were used, obtained from a marine farm in Sagunto (Spain) with a weight $14.1 \pm 0.9 \mathrm{~g}$ and total length $10.5 \pm 0.2 \mathrm{~cm}$ (mean \pm standard deviation). The fish were maintained in a circular tank (radius $2 \mathrm{~m}$, water depth $0.75 \mathrm{~m}$ ). The water in the tank was filtered and recirculated with a constant temperature of $12 \pm 2{ }^{\circ} \mathrm{C}$ and a dissolved oxygen concentration of $8 \mathrm{mg}^{-1}$.The fish were maintained in a natural photoperiod and fed with commercial dry pellets $(0.5 \%$ of their body weight). To acclimatize, the animals were moved to the experimental tank (which was identical to the maintenance tank) and not fed for $24 \mathrm{~h}$ before the experiment. Experiments were conducted under authorisation of the Dirección General de Producción Agraria y Ganadería, Generalitat Valenciana, Spain (Authorisation No. 2018/VSC/PEA/0156).

\section{Acoustics emission and recording systems}

The fish were continuously stressed for $7 \mathrm{~h}$ with white noise filtered at third-octave frequencies of $63 \mathrm{~Hz}, 125 \mathrm{~Hz}$, $500 \mathrm{~Hz}$, and $1000 \mathrm{~Hz}$ at a sound pressure level (SPL) of between 140 and $150 \mathrm{~dB}$ re $1 \mu \mathrm{Pa}$ at $1 \mathrm{~m}$ (Fig. 1). This range of frequencies was chosen because the hearing of most fish species is sensitive at frequencies of up to $1 \mathrm{kHz}$ (Popper et al., 2003) and also because it includes the $63 \mathrm{~Hz}$ and $125 \mathrm{~Hz}$ centre frequencies as indicated in the MSFD as the descriptors to monitor the level of low frequency continuous noise in the sea (Dekeling et al., 2014).

The acoustic experimental setup to emit sounds in the tank consisted of an electroacoustic system composed of a RedPitaya Digital Acquisition (DAQ) board (Red Pitaya d.d., Solkan, Slovenia) connected to an amplifier (TA-F161 Sony Integrated Stereo Amplifier, Sony Corporation, Tokyo, Japan) 


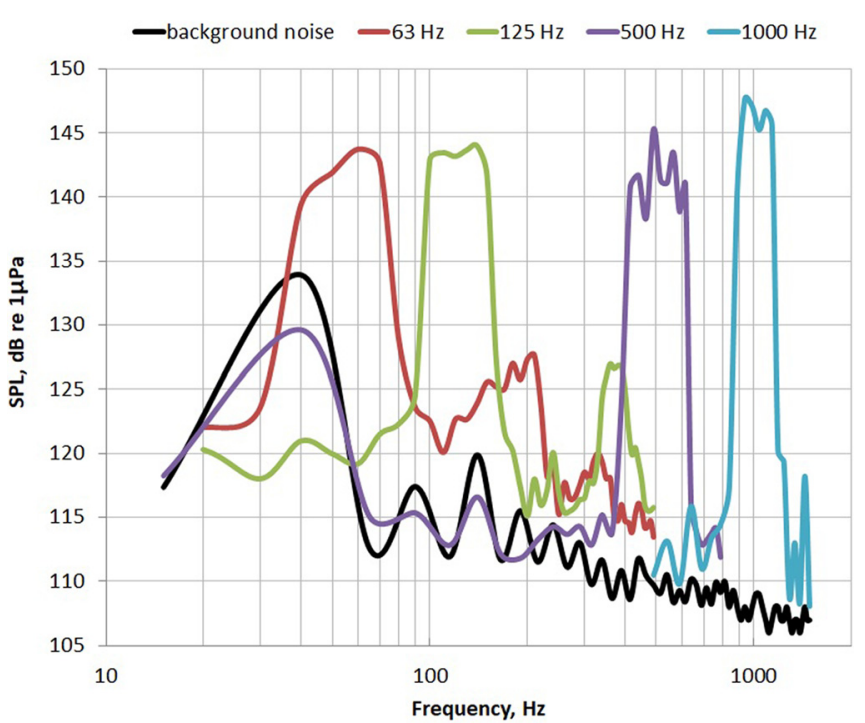

FIG. 1. (Color online) Power spectrum ( $\mathrm{dB}$ re $1 \mu \mathrm{Pa}$ ) of tank background noise and different acoustic stimulus. Logarithmic scale on the $x$ axis. Sampling frequency $6000 \mathrm{~Hz}$, fast Fourier transform (FFT) length of 256, frequency resolution $24 \mathrm{~Hz}$, Hamming window, and overlap $50 \%$.

and finally feeding into a loudspeaker (Beyma-UA-UPV prototype, Acustica Beyma, Valencia, Spain). The loudspeaker was previously calibrated using a reference hydrophone (Reson TC4034, Teledyne Reson, Slangerup, Danimarca). Signals with a SPL of $150 \mathrm{~dB}$ at each frequency band were generated using a MATLAB® code (The MathWorks, Natick, MA) specifically developed for this work. The loudspeaker was located on the side of the experimental tank without touching the wall.

For controlling the noise in the experimental tank both during control and experimental trials, we used a calibrated hydrophone (Reson TC4034, Slangerup, Danimarca) connected to a Red Pitaya DAQ board (Solkan, Slovenia) operating at a sampling frequency of $7.6 \mathrm{kHz}$.

To ensure that the experimental and maintenance tanks were acoustically isolated, preliminary recordings of acoustic ambient noise in the maintenance tank were carried out with the emission system in the experimental tank switched both on and off.

The experimental trials and controls were carried out in the same tank, following a random order, so that problems due to sound transmission were avoided. The estimated sound exposure level for $7 \mathrm{~h}$ ranged from 184 to $194 \mathrm{~dB}$ re $1 \mu \mathrm{Pa}^{2} \mathrm{~s}$.

\section{Experimental plan}

In total, 15 trials were performed consisting of 3 test replicates for each experimental frequency $(63,125,500$, and $1000 \mathrm{~Hz}$ ) and a further 3 replicates for the control trial, keeping the speaker turned on but without any sound emission. This setup was chosen to avoid possible differences between the experimental and control trials due to the electromagnetic field (Fig. 2).

For each replicate, 6 fish were used, totalling 90 fish across all the trials. To eliminate the effect of possible variation in light and temperature conditions, the trials were performed in

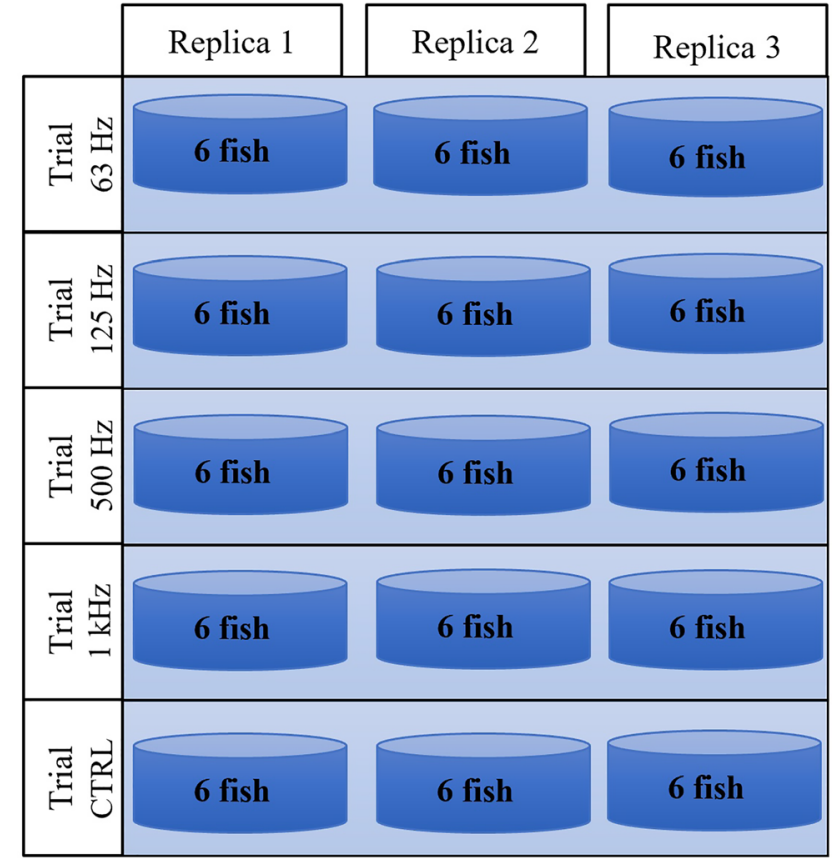

FIG. 2. (Color online) Experimental plan with replicas for each of four frequency bands and controls.

random order, and the total duration of the experiments was kept to a minimum (approximately one month).

The animals to be tested were randomly selected from the maintenance tank $24 \mathrm{~h}$ before the beginning of each trial and transferred to the experimental tank for acclimatization. The hydrophone and the underwater speaker were present in the tank during all the trials, including during the control trials (without acoustic signal generation). Each trial lasted a total of 435 min: 15 min before the sound emission followed by $420 \mathrm{~min}(7 \mathrm{~h})$ of acoustic exposure.

For this study, we considered the habituation response as being defined as "a relative persistent waning of a response as a result of repeated stimulation, which is not followed by any kind of reinforcement" (Thorpe, 1963; Bejder et al., 2009). In the experiments, the habituation response can therefore be measured as a return of behaviour similar to the control condition. To assess the habituation response to the acoustic stress, considering the limitations in the specifications (in particular battery life) of the two cameras, we chose a specific sampling design for video collection. In each trial, the sampling was divided temporally as follows:

- 15 min before the acoustic emission (before),

- the first 60 min of the acoustic stress emission (D1), and

- the final $15 \mathrm{~min}$ of every hour for the following $6 \mathrm{~h}$ during which the acoustic stress was emitted (D2-D7).

\section{B. Behavioural analysis}

To facilitate the monitoring of the fish behaviour with the video cameras, the fish were confined in a smaller cylindrical net cage (height $1.40 \mathrm{~m}$ and diameter $75 \mathrm{~cm}$ ). The behaviour of the animals was recorded using an underwater 
camera (GoPro HERO4, GoPro, Inc., San Mateo, California) located $1 \mathrm{~m}$ horizontal distance from the cage at a depth of $0.35 \mathrm{~m}$ and an external (in-air) camera (Axis camera 1346, Axis Communications, Lund, Sweden) placed at a distance of $1 \mathrm{~m}$ from the top of the cage looking downward (Fig. 3). This arrangement was chosen to make the whole cage visible in both camera's field of view.

For each trial, the camera positioned on the top of the cage (see Fig. 3) recorded for a total of $165 \mathrm{~min}$ : $15 \mathrm{~min}$ before sound emission (before), then $60 \mathrm{~min}$ during the acoustic emission (D1), and again during the final $15 \mathrm{~min}$ of each hour for the next $6 \mathrm{~h}$ of acoustic emission (D2-D7). The underwater camera, used for recording the swimming height, recorded only $60 \mathrm{~min}$ (during the D1 period) due to battery limitations (see Fig. 3).

Analysis of the recorded videos was performed to evaluate dispersion, motility, and swimming height in the water column (Table I). These parameters were chosen because other authors demonstrated their effectiveness in highlighting behavioural responses following an acoustic stress (Buscaino et al., 2010; Hawkins et al., 2014; Neo et al., 2014; Neo et al., 2015;, Neo et al., 2016; Nedelec et al., 2016).

The dispersion and the motility behaviours were assessed using recordings from the top-down camera while swimming height was assessed using recordings from the underwater camera. To extract the dispersion and motility data, the bottom of the cage was virtually divided into a grid of $15 \mathrm{~cm}$ squares [the total surface of the bottom was $4416 \mathrm{~cm}^{2}$; see Fig. 3(a)]. For the swimming height evaluation, the water column was virtually divided into three zones: zone zero (the deepest), zone one (intermediate), and zone two [the highest; see Fig. 3(b)]. The video recordings were visualized for the analysis using Windows Media Player Classic (Microsoft Corporation, Redmond, Washington).

\section{Dispersion}

To analyse the dispersion, the recordings from the video camera positioned above the tank were used. These recordings framed the bottom of the cage net in the field of view. Dispersion was calculated by counting the number of squares occupied by the fish (by virtually drawing a closed polygon around the fish group) in one still image every $30 \mathrm{~s}$ (see Table I). The area occupied was expressed as $\mathrm{cm}^{2}$ per still image. The first measurement was collected at time zero.

\section{Motility}

For the motility analyses, the same recordings were used as for the dispersion. A $10 \mathrm{~s}$ snippet of video was (a)

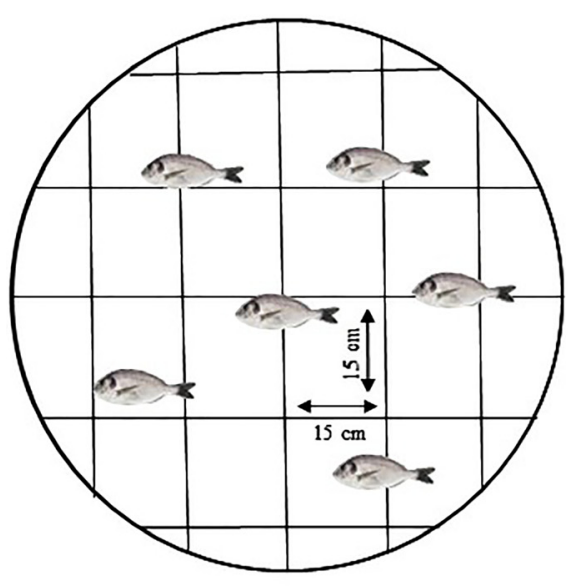

(b)

\section{External camera}

$\longrightarrow$

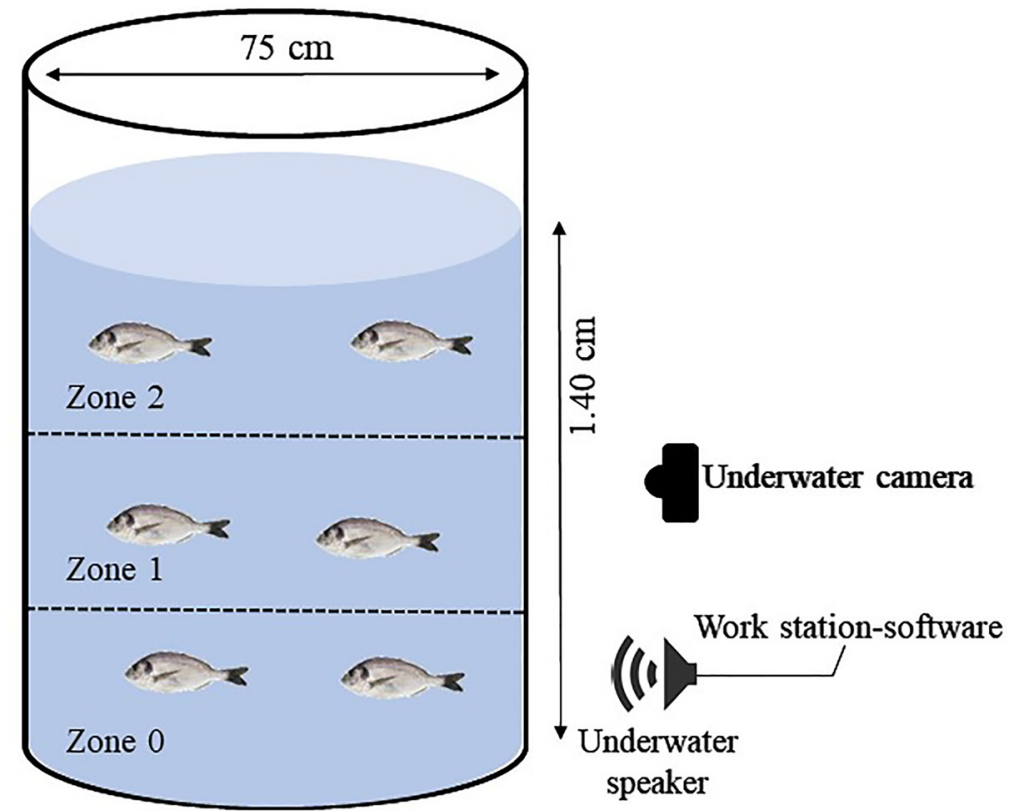

(c)

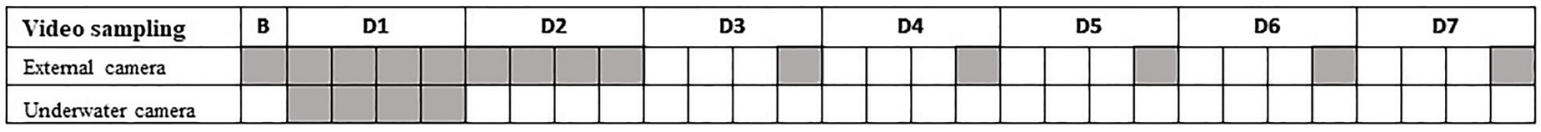

FIG. 3. (Color online) (a) Schematic representation of the grid created at the bottom of the basket for the study of dispersion and motility of fish. (b) Schematic representation of the cylindrical cage net, underwater speaker, and external and underwater cameras; the water column was ideally divided into three parts to study the swimming height of fish: zero zone (lower), one zone (intermediate), two zone (higher). (c) Timing of each trial and video monitoring. Each square represents $15 \mathrm{~min}$. 
TABLE I. Behavioural categories description.

\begin{tabular}{|c|c|c|c|c|}
\hline & Description & Sampling design & Sampling effort & Unit \\
\hline Dispersion & $\begin{array}{l}\text { Area occupied by fish measured as the } \\
\text { number of squares occupied by fish } \\
\text { multiplied by the single square area } \\
\qquad\left(225 \mathrm{~cm}^{2}\right)\end{array}$ & $\begin{array}{l}\text { Instantaneous sampling on a } 30 \mathrm{~s} \\
\text { grid (in before, during, and post } \\
\text { periods) }\end{array}$ & $\begin{array}{l}338 \text { frames per trial and } 5070 \text { frames } \\
\text { in total }\end{array}$ & $\mathrm{cm}^{2}$ \\
\hline Motility & $\begin{array}{c}\text { The number of squares crossed by each } \\
\text { of six fish in } 10 \mathrm{~s} \text {. These six values were } \\
\text { averaged. }\end{array}$ & One measurement every $5 \mathrm{~min}$ & $\begin{array}{c}41 \text { values for each trial and } 615 \\
\text { values in total }\end{array}$ & $\mathrm{cm} / \mathrm{s}$ \\
\hline $\begin{array}{l}\text { Swimming } \\
\text { height }\end{array}$ & $\begin{array}{l}\text { The zone occupied by each of six fish. } \\
\text { These six values were averaged. }\end{array}$ & $\begin{array}{l}\text { One measurement every } 5 \mathrm{~min} \\
\quad \text { (only the during period). }\end{array}$ & $\begin{array}{c}13 \text { values for each trial and } 195 \\
\text { values in total }\end{array}$ & $\begin{array}{l}\text { Dimensionless } \\
\text { index }\end{array}$ \\
\hline
\end{tabular}

analysed every $5 \mathrm{~min}$ of the recording (starting at time zero). For each snippet, the number of grid squares crossed by each fish in that time period was counted (see Table I). The number of squares was then converted into an approximate swimming speed $(\mathrm{cm} / \mathrm{s})$ by considering the size of each square $\left(15 \mathrm{~cm}^{2}\right)$ and the time period of analysis $(10 \mathrm{~s})$. In this way, the motility was evaluated for each fish and then averaged.

\section{Swimming height}

The swimming height was obtained using the underwater camera (GoPro, Inc.) video recordings [see Fig. 3(b)], which viewed the side of the cage net. Every $5 \mathrm{~min}$, starting at time zero, the zone occupied by each fish was noted (see Table I). These six values were averaged. This parameter was measured only during the first hour of acoustic emission (D1).

\section{Statistical analysis}

The experiments were performed with three replicates for each sound emission frequency and another three replicates for the control trial (Fig. 2). Dispersion, motility, and swimming height data were tested for normal distribution using Shapiro-Wilk tests.

Non-parametric U-Mann Whitney tests were carried out to evaluate differences in dispersion and motility between the control and acoustic trials for each period of sampling.

To investigate the nonlinear effect of the experimental time (before and during the noise exposure) on behavioural parameters, generalized additive models (GAMs) were carried out for each trial using the mgcv package (Wood et al., 2016) in $R$ (version 3.4.0). Dispersion and motility parameters were used as dependent variables and the experimental time was used as a smooth term. The family distribution applied in the models was changed according to the results of normal distribution tests (Gaussian family for normally distributed data and Gamma family for non-normal distributed data). The model diagnostic was checked for each model. Concerning the swimming height, the Kruskal-Wallis test and multiple comparisons post hoc test were applied, comparing different trials only for the first hour of acoustic exposure (D1).

\section{RESULTS}

The analysis of the dispersion and motility behaviours in the 15 min sampling periods before acoustic emission started did not show any significant differences between the test and control groups (Table II). Differences were, however, observed during the sound exposure as described in Secs. III A-III C.

TABLE II. Results of U-Mann Whitney test to explore significant differences in the dispersion and motility behaviours between control groups and each test group at different frequency bands $(1 / 3$ octave band centred at 63 , 125,500 , and $1000 \mathrm{~Hz}$ ) inside each period (before, D1, D2, D3, D4, D5, D6, D7). Bold values indicate significant differences between control groups and test groups.

\begin{tabular}{|c|c|c|c|c|c|c|c|}
\hline & & \multicolumn{3}{|c|}{ Dispersion } & \multicolumn{3}{|c|}{ Motility } \\
\hline & & $Z$ & $p$-level & Valid $N$ & $Z$ & $p$-level & Valid $N$ \\
\hline \multirow[t]{8}{*}{$63 \mathrm{~Hz}$} & Before & -0.64 & 0.5221 & 93 & 0.84 & 0.4025 & 12 \\
\hline & D1 & 12.64 & 0.0000 & 363 & 5.64 & 0.0000 & 39 \\
\hline & D2 & 3.54 & 0.0005 & 93 & 3.97 & 0.0001 & 12 \\
\hline & D3 & 0.94 & 0.3488 & 93 & 2.25 & 0.0243 & 12 \\
\hline & D4 & -0.85 & 0.3969 & 93 & 2.92 & 0.0036 & 12 \\
\hline & D5 & -1.32 & 0.1865 & 93 & 3.03 & 0.0024 & 12 \\
\hline & D6 & -0.85 & 0.3931 & 93 & 2.25 & 0.0243 & 12 \\
\hline & D7 & 0.72 & 0.4721 & 93 & 3.03 & 0.0024 & 12 \\
\hline \multirow[t]{8}{*}{$125 \mathrm{~Hz}$} & Before & -1.33 & 0.1838 & 93 & -0.03 & 0.9770 & 12 \\
\hline & D1 & 15.94 & 0.0000 & 363 & 5.61 & 0.0000 & 39 \\
\hline & D2 & 2.62 & 0.0094 & 93 & 3.80 & 0.0002 & 12 \\
\hline & D3 & 0.20 & 0.8445 & 93 & 0.61 & 0.5444 & 12 \\
\hline & D4 & 0.68 & 0.4942 & 93 & -0.78 & 0.4357 & 12 \\
\hline & D5 & 1.97 & 0.0484 & 93 & -1.48 & 0.1379 & 10 \\
\hline & D6 & 1.57 & 0.1167 & 93 & 0.32 & 0.7508 & 12 \\
\hline & D7 & 1.42 & 0.1543 & 93 & 1.04 & 0.2987 & 12 \\
\hline \multirow[t]{8}{*}{$500 \mathrm{~Hz}$} & Before & -0.25 & 0.7990 & 93 & 0.12 & 0.9081 & 12 \\
\hline & D1 & 4.17 & 0.0000 & 363 & 0.24 & 0.8105 & 39 \\
\hline & D2 & -0.13 & 0.9003 & 93 & 1.94 & 0.0531 & 12 \\
\hline & D3 & -1.27 & 0.2053 & 93 & 0.75 & 0.4529 & 12 \\
\hline & D4 & -1.10 & 0.2700 & 93 & 1.50 & 0.1333 & 12 \\
\hline & D5 & -0.16 & 0.8755 & 93 & -0.20 & 0.8399 & 12 \\
\hline & D6 & -2.59 & 0.0095 & 93 & 0.06 & 0.95402 & 12 \\
\hline & D7 & -4.01 & 0.0001 & 93 & 0.00 & 10.000 & 12 \\
\hline \multirow[t]{8}{*}{$1 \mathrm{kHz}$} & Before & 0.88 & 0.3797 & 93 & 0.09 & 0.9310 & 12 \\
\hline & D1 & 0.43 & 0.6692 & 363 & 1.31 & 0.1888 & 39 \\
\hline & D2 & -3.18 & 0.0017 & 93 & 0.70 & 0.4884 & 12 \\
\hline & D3 & -3.79 & 0.0001 & 93 & 1.85 & 0.0647 & 12 \\
\hline & D4 & -1.57 & 0.1163 & 93 & 3.12 & 0.0018 & 12 \\
\hline & D5 & -3.25 & 0.0012 & 93 & 1.53 & 0.1260 & 12 \\
\hline & D6 & -3.16 & 0.0016 & 93 & 3.26 & 0.0011 & 12 \\
\hline & D7 & -3.93 & 0.0001 & 93 & 1.33 & 0.1842 & 12 \\
\hline
\end{tabular}




\section{A. Dispersion behaviour}

The analysis of dispersion showed significant differences during the first hour of acoustic emission (D1) for all frequencies except for $1 \mathrm{kHz}$ (Table II and Fig. 4). During this period, a large decrease in dispersion was observed (equivalent to an increase in cohesion) as compared to the control groups. For example, for $125 \mathrm{~Hz}$, before emission started the dispersion was $2922 \pm 631 \mathrm{~cm}^{2}$ (mean $\pm \mathrm{SD}$ ), while during D1 the values decrease to $1939 \pm 603 \mathrm{~cm}^{2}$. At the lower sound frequencies ( 63 and $125 \mathrm{~Hz}$ ), the differences between the control and acoustic groups decreased with time of exposure (Fig. 4) with a gradual return to approximately the control values. At these frequencies the sound exposures had an immediate behavioural effect visible in the first two hours of emission that was greatest at $125 \mathrm{~Hz}$. After that, a gradual habituation effect was observed. At $63 \mathrm{~Hz}$, the specimens showed values comparable to the control at the third hour, which remained for the last five hours of exposure, whereas at $125 \mathrm{~Hz}$ the average dispersion stayed slightly lower with a significant decrease occurring at the fifth hour of exposure (D5).

Conversely, at the higher frequencies $(500 \mathrm{~Hz}$ and $1 \mathrm{kHz})$, the differences increased over time with higher values for the acoustic test groups compared to the control groups.

For the $500 \mathrm{~Hz}$ tests, a significant reduction in dispersion was observed during the first hour of acoustic emission
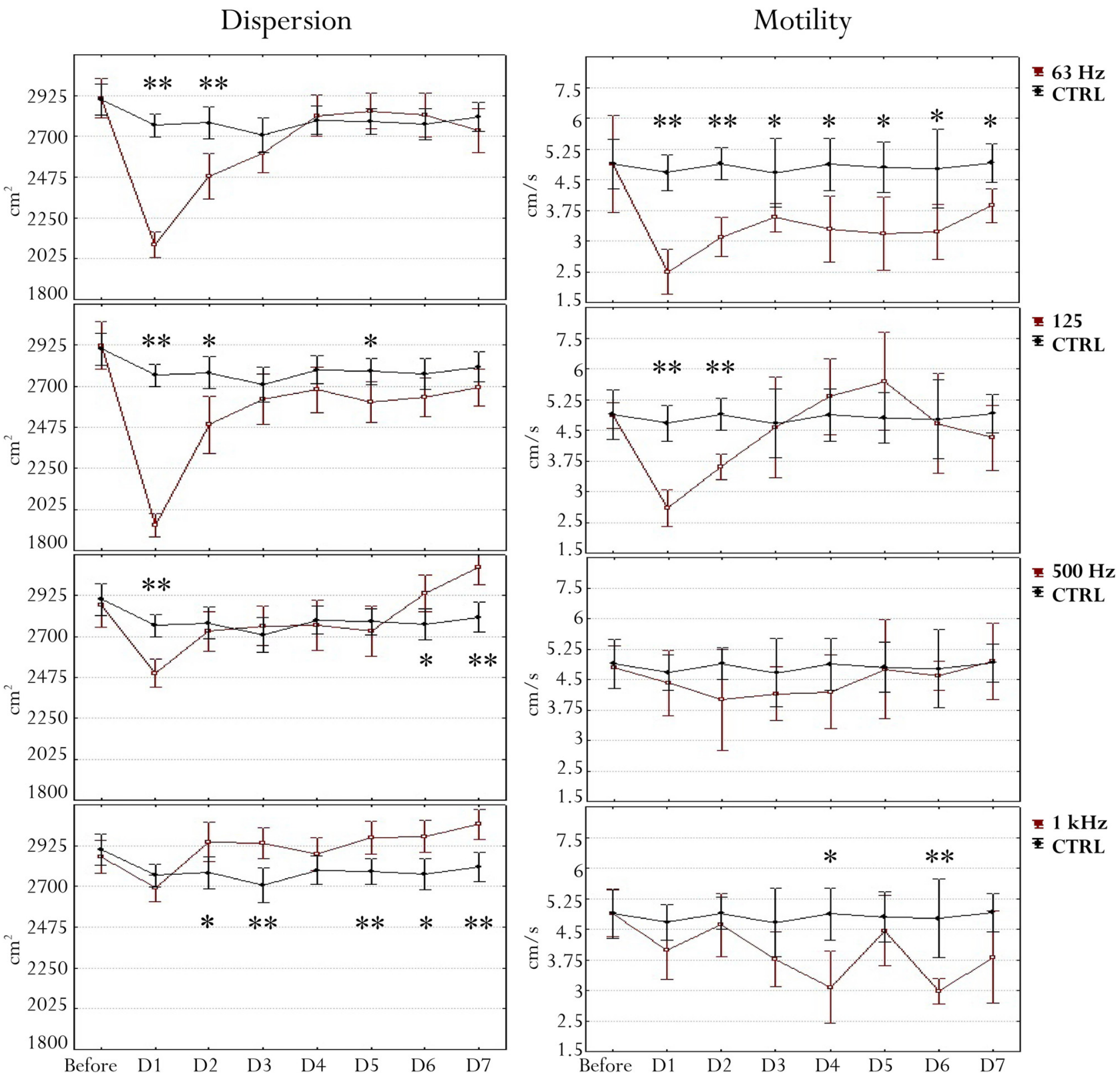

FIG. 4. (Color online) (Left) Mean $\pm 95 \%$ confidence interval of the dispersion obtained for each replicate by counting the number of squares occupied by the group of fish every $30 \mathrm{~s}$. (Right) Mean $\pm 95 \%$ confidence interval of motility obtained for each replicate by counting the number of squares crossed by each fish in $10 \mathrm{~s}$ and then averaged. Statistical differences are shown within the same period between the control and acoustic groups $(* p<0.05$, $* * p<0.0001)$. 
followed by a significant increase in the last two hours. For the $1 \mathrm{kHz}$ tests, the animals' dispersion increased significantly after the second hour of emission.

The GAMs analysis confirmed the effect of time of exposure at all frequencies (see Table III) with higher explained deviance in $63 \mathrm{~Hz}, 125 \mathrm{~Hz}$, and $500 \mathrm{~Hz}$. The smooth term for the control trial significantly modelled the data but with a very low explained deviance (4.1\%).

\section{B. Motility behaviour}

A general and significant decrease of motility was observed for the fish exposed to acoustic noise. As was observed for dispersion, this reduction was largest in the first hour of exposition (D1). The analysis of motility showed significant differences during the first hour of acoustic emission (D1) at $63 \mathrm{~Hz}$ and $125 \mathrm{~Hz}$ (Table II and Fig. 4) with values that changed from $3.3 \pm 1.3 \mathrm{~cm} / \mathrm{s}$ to $1.5 \pm 1.1 \mathrm{~cm} / \mathrm{s}$ for the $63 \mathrm{~Hz}$ trial and from $3.2 \pm 0.3 \mathrm{~cm} / \mathrm{s}$ to $1.7 \pm 0.9 \mathrm{~cm} / \mathrm{s}$ for the $125 \mathrm{~Hz}$ trial. At $63 \mathrm{~Hz}$, the animals did not return to the control values for the rest of the trial, while at $125 \mathrm{~Hz}$, they showed similar motility values to control after $3 \mathrm{~h}$ of exposure (D3).

At $500 \mathrm{~Hz}$, no significant differences were observed between the control and acoustic test groups even though, on average, lower values of motility were recorded during

TABLE III. Results of the generalized additive models (GAMs) considering as dependent variables, dispersion and motility parameters, and as smooth term, the experimental time; edf is effective degrees of freedom.

\begin{tabular}{|c|c|c|c|c|c|c|}
\hline \multicolumn{7}{|c|}{ Dispersion $\sim \mathrm{s}$ (experimental time) } \\
\hline \multirow[t]{20}{*}{ Trials } & Control $(n=1011)$ & & Estimate & Standard error & $t$ value & $p$ value \\
\hline & & Intercept & 7.93 & 0.005 & 1541 & 0.001 \\
\hline & & & edf & $F$ & $p$ value & Deviance explained \\
\hline & & Smooth term (experimental time) & 8.359 & 1.45 & $<0.001$ & $4.09 \%$ \\
\hline & $63 \mathrm{~Hz}(n=1014)$ & & Estimate & Standard error & $t$ value & $p$ value \\
\hline & & Intercept & 7.811 & 0.0069 & 1123 & 0.001 \\
\hline & & & edf & $F$ & $p$ value & Deviance explained \\
\hline & & Smooth term (experimental time) & 23.62 & 26 & $<0.001$ & $40.20 \%$ \\
\hline & $125 \mathrm{~Hz}(n=997)$ & & Estimate & Standard error & $t$ value & $p$ value \\
\hline & & Intercept & 7.789 & 0.00693 & 1124 & 0.001 \\
\hline & & & edf & $F$ & $p$ value & Deviance explained \\
\hline & & Smooth term (experimental time) & 21.41 & 23.28 & $<0.001$ & $33.10 \%$ \\
\hline & $500 \mathrm{~Hz}(n=1004)$ & & Estimate & Standard error & $t$ value & $p$ value \\
\hline & & Intercept & 7.905 & 0.00628 & 1259 & 0.001 \\
\hline & & & edf & $F$ & $p$ value & Deviance explained \\
\hline & & Smooth term (experimental time) & 26.24 & 25.45 & $<0.001$ & $34.60 \%$ \\
\hline & $1 \mathrm{kHz}(n=1013)$ & & Estimate & Standard error & $t$ value & $p$ value \\
\hline & & Intercept & 7.9511 & 0.005921 & 1343 & 0.001 \\
\hline & & & edf & $F$ & $p$ value & Deviance explained \\
\hline & & Smooth term (experimental time) & 24.6 & 14.26 & $<0.001$ & $25.50 \%$ \\
\hline \multicolumn{7}{|c|}{ Motility $\sim \mathrm{s}$ (experimental time) } \\
\hline \multirow[t]{20}{*}{ Trials } & Control $(n=123)$ & & Estimate & Standard error & $t$ value & $p$ value \\
\hline & & Intercept & 3.185 & 0.068 & 46.7 & $<0.001$ \\
\hline & & & edf & $F$ & $p$ value & Deviance explained \\
\hline & & Smooth term (experimental time) & 1 & 0.22 & 0.622 & $0.20 \%$ \\
\hline & $63 \mathrm{~Hz}(n=119)$ & & Estimate & Standard error & $t$ value & $p$ value \\
\hline & & Intercept & 2.179 & 0.079 & 27.5 & $<0.001$ \\
\hline & & & edf & $F$ & $p$ value & Deviance explained \\
\hline & & Smooth term (experimental time) & 6.881 & 4.009 & $<0.001$ & $25.70 \%$ \\
\hline & $125 \mathrm{~Hz}(n=997)$ & & Estimate & Standard error & $t$ value & $p$ value \\
\hline & & Intercept & 2447.24 & 16.56 & 147.8 & $<0.001$ \\
\hline & & & edf & $F$ & $p$ value & Deviance explained \\
\hline & & Smooth term (experimental time) & 12.55 & 37.41 & $\mathrm{p}<0.001$ & $33.30 \%$ \\
\hline & $500 \mathrm{~Hz}(n=118)$ & & Estimate & Standard error & $t$ value & $p$ value \\
\hline & & Intercept & 1.119 & 0.029 & 38.2 & $<0.001$ \\
\hline & & & edf & $F$ & $p$ value & Deviance explained \\
\hline & & Smooth term (experimental time) & 7.78 & 2.56 & $<0.05$ & $16.50 \%$ \\
\hline & $1 \mathrm{kHz}(n=121)$ & & Estimate & Standard error & $t$ value & $p$ value \\
\hline & & Intercept & 2.68 & 0.0947 & 28.29 & $p<0.001$ \\
\hline & & & edf & $F$ & $p$ value & Deviance explained \\
\hline & & Smooth term (experimental time) & 4.309 & 1.418 & 0.212 & $7.90 \%$ \\
\hline
\end{tabular}


the first $4 \mathrm{~h}$ of acoustic exposure. The $1 \mathrm{kHz}$ groups showed significant differences compared to control groups after 4 and $6 \mathrm{~h}$ (D4 and D6) of exposure to the noise (see Fig. 4).

In summary, the time of exposure was found to significantly affect the motility behaviour of the fish at most of the tested acoustic frequencies $(63,125$, and $500 \mathrm{~Hz})$ with higher explained deviance for the $63 \mathrm{~Hz}$ and $125 \mathrm{~Hz}$ trials. No significant effect was found for the control group and the highest test frequency of $1 \mathrm{kHz}$ (Table III) .

\section{Swimming height behaviour}

Fish exposed to noise were generally observed to swim toward the bottom (Fig. 5). The swimming height of the fish, assessed during the first hour of acoustic exposure, showed significant differences between the acoustic groups and the control groups (Table IV). Only the $125 \mathrm{~Hz}$ tests showed no significant differences compared to the control group (Table IV).

\section{DISCUSSION}

The results of this study have highlighted significant variations in the behavioural responses of juvenile fish depending on the exposure to different acoustic frequencies. The greatest impact was observed at lower acoustic frequencies $(1 / 3$ octave bands centred at $63 \mathrm{~Hz}$ and $125 \mathrm{~Hz})$. However, the higher frequencies also elicited significant behavioural changes, especially during the final few hours of monitoring (see, for example, the dispersion at $1 \mathrm{kHz}$ ).

Control specimens were observed to occupy a larger area with higher dispersion levels compared to the trials in which specimens were exposed to sound. However, the control groups still tended to occupy only half of the available area, on average, despite the lack of acoustic stimulus. Considering that our study was carried out during daylight hours, this result is in agreement with Hawkins et al. (2012), who observed a greater cohesion during daylight hours in

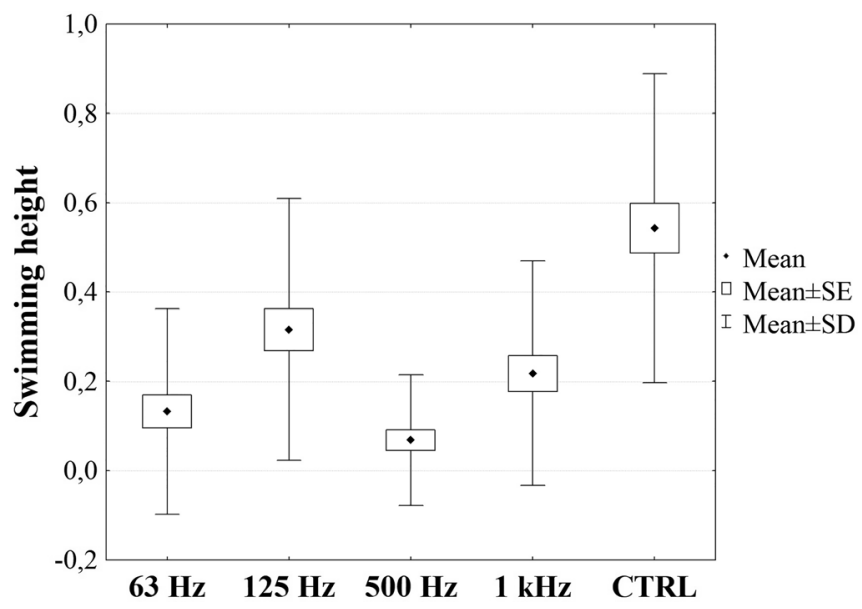

FIG. 5. Swimming height obtained by dividing the water column into different zones: 0 for the lowest, 1 for the middle, and 2 for the highest. The multiple comparison post hoc test showed significant differences between control (CTRL) trials versus all sound frequency trials $(p<0.05)$ other than the $125 \mathrm{~Hz}$ trials $(p=0.13)$.
TABLE IV. Results of the Kruskal-Wallis (K-W) test and the multiple comparisons post hoc test for swimming height ( $z$ ' values) measured in the different trials. Bold values of the test are significant at $p<0.05$ and bold values with "**" are significant at $p<0.0001$.

\begin{tabular}{lcccccc}
\hline \hline & & $63 \mathrm{~Hz}$ & $125 \mathrm{~Hz}$ & $500 \mathrm{~Hz}$ & $1 \mathrm{kHz}$ & Control \\
\hline $63 \mathrm{~Hz}$ & $\mathrm{~K}-\mathrm{W}$ test $H$ & & $\mathbf{2 . 8 2}$ & 0.92 & 1.51 & $\mathbf{5 . 2 9 *}$ \\
$125 \mathrm{~Hz}$ & $(4, N=195)=54.5$ & $\mathbf{2 . 8 2}$ & & $\mathbf{3 . 7 4}$ & 1.31 & 2.47 \\
$500 \mathrm{~Hz}$ & $\boldsymbol{p}<\mathbf{0 . 0 0 0 1}$ & 0.92 & $\mathbf{3 . 7 4}$ & & 2.43 & $\mathbf{6 . 2 1 *}$ \\
$1 \mathrm{kHz}$ & & 1.51 & 1.31 & 2.43 & & $\mathbf{3 . 7 8}$ \\
Control & & $\mathbf{5 . 2 9 *}$ & 2.47 & $\mathbf{6 . 2 1} *$ & $\mathbf{3 . 7 8}$ & \\
\hline \hline
\end{tabular}

fish Sprattus sprattus exposed to acoustic stress. Our results demonstrated that all frequencies tested had a significant effect on the dispersion. The initial effects were noticeably different depending on the frequency of the emitted sound but generally occurred immediately after exposure to the noise. The fish also showed evidence of returning to control behaviour over time, depending on the particular acoustic frequency.

The variability in the dispersion of the group can be explained by changes in swimming speed responses and different freezing responses. During the low frequency exposures $(63$ and $125 \mathrm{~Hz})$ at the start of the acoustic emission, the animals reacted quickly by grouping at a single point very close to each other with evident freezing reactions. At higher frequencies $(500 \mathrm{~Hz}$ and $1 \mathrm{kHz})$, on the other hand, the animals reacted to the sound not by grouping at a single point but by immediately stopping at the point where they were at the start of the acoustic emission with shorter freezing reactions than the low frequencies followed by rapid movements from point to point in the cage.

Our results confirmed the effect of anthropogenic noise on group dispersion and they are in agreement with the formation of closer groups as described in Fewtrell and McCauley (2012). We confirm that dispersion can be a good behavioural impact indicator, even using a small experimental arena in which the ability of the individuals to see each other is elevated.

Regarding motility, significant effects on behaviour were found during the first hour of sound exposure at lower frequencies $(63 \mathrm{~Hz}$ and $125 \mathrm{~Hz})$. The reduction in motility observed at these frequencies is not in agreement with the results obtained by Buscaino et al. (2010) and Neo et al. (2016), who tested animals at frequencies ranging between $100 \mathrm{~Hz}$ and $1 \mathrm{kHz}$. However, adult individuals of $S$. aurata and slightly different acoustic frequencies were used in those studies and, for this reason, a different response in juveniles might be expected (Holmes et al., 2017; Ferrari et al., 2018).

The measured recovery of motility over time, returning to control values, could be due to habituation or sensory adaptation and/or muscle fatigue (Domjan, 2010; Neo et al., 2014). Out of the two lowest tested frequencies, $63 \mathrm{~Hz}$ appeared to have the most impact with the fish never showing a recovery behaviour. Conversely, at $125 \mathrm{~Hz}$, the fish returned to the control values during the third hour of 
exposure and subsequently exceeded them. These increases in speed, even if not significant, may also be caused by sudden reactions and accelerations (Blaxter et al., 1981; Fewtrell and McCauley, 2012; Kastelein et al., 2008; Pearson et al., 1992; Purser and Radford, 2011; Wardle et al., 2001). Reactions of this type were also observed in our study during the $1 \mathrm{kHz}$ trials, which showed higher variability in the motility measurements. A considerable amount of attack and startle reactions were observed at this stimulus frequency, which influenced the motility. It is probable that the animals became more irritated or frightened. Such reactions are essential anti-predation and anxiety behaviours (Cachat et al., 2010), and their variations could indicate a negative impact of low frequencies on fish motility.

The swimming depth significantly decreased during all tested exposure frequencies other than $125 \mathrm{~Hz}$. This observation of a change in swimming depth due to noise is in agreement with the results of Sarà et al. (2007), in which tuna were subjected to motorboat noise. Several other studies have shown that fish dive deeper after noise exposure, resulting in movement vertically down through the water column and not horizontally (Doksæter et al., 2012; Fewtrell and McCauley, 2012; Gerlotto and Fréon, 1992; Handegard et al., 2003; Slotte et al., 2004). Our results are also in agreement with Neo et al. (2016), who observed an increase in swimming depth in $S$. aurata adults in response to an acoustic stress. They also observed that the fish, when exposed to an acoustic stimulus, tended to swim closer to the emitter while increasing their swimming depth. This was explained as a possible phonotactic response due to curiosity toward the sound emitted (Nelson and Johnson, 1972; Weilgart, 2007). However, in our study, the greater depth of swimming due to curiosity can be discounted because the fish tended to be in the part of the basket that was more distant from the acoustic emitter. The observed behaviour of swimming toward the bed could be due to anxiety (Cachat et al., 2010; Israeli-Weinstein and Kimmel, 1998; Kuwada et al., 2000; Luca and Gerlai, 2012; Skilbrei and Holst, 2009; Wilson and Dill, 2002), which is also observed in outdoor studies (Gerlotto and Fréon, 1992; Handegard et al., 2003; Slotte et al., 2004). Our study confirms that swimming depth can be a good behavioural indicator of response to stress, demonstrating an attempt to escape and perhaps a reduction in risk of predation.

The acoustic field generated inside the tank was not characterized in detail during the experimental measurements; it was considered that at the main frequencies of interest, $63 \mathrm{~Hz}$ and $125 \mathrm{~Hz}$, the wavelength associated was on the order of 23 $\mathrm{m}$ and $12 \mathrm{~m}$, respectively. At these wavelengths, and considering the dimensions of the tank, no significant effects of own mode vibration are expected. However, it is recognised that slight variations in the acoustic sound field due to acoustic reverberation and interference phenomena could have influenced the fish movements inside the tank. For this reason, it is necessary to carefully interpret our results, and further validation should be performed in the future against observed behavioural responses of this species in the wild.
Some of the variability in behavioural responses between the low and high frequency exposures could possibly be due to differing sound sensitivities of the fish. Currently, the audiogram of many fish species, in this case juvenile $S$. aurata, is not known, but the frequency ranges from 50 and $1122 \mathrm{~Hz}$ (with a SPL of $140-150 \mathrm{~dB}$ re $1 \mu \mathrm{Pa}$ ) are generally heard by most fish species (Popper et al., 2003). Although more studies are needed to confirm our findings, our results suggest that the fish responded differently to the frequencies used in experiments.

The observed recovery time could be due to either habituation or sensory adaptation (Domjan, 2010). The possibility of a species becoming accustomed to an acoustic stress has been observed in a number of previous studies (Neo et al., 2014; Neo et al., 2015; Neo et al., 2016; Neo et al., 2018; Nedelec et al., 2016) and, in accordance with Neo et al. (2014), the continuous noise used in our experiments may have favoured a partial habituation effect compared to an intermittent noise. When an organism is exposed to a continuous noise, it is subjected to a continuous stimulation that involves a rapid habituation to stress and therefore a more rapid recovery (Rankin and Broster, 1992; Rankin et al., 2009). Conversely, in the presence of intermittent sounds, the recovery to pre-exposure levels in sea bass has been observed to be slower (Neo et al., 2014; Koolhaas et al., 2011; Rankin et al., 2009).

In the present study, we did not consider the full recovery of the measured parameters since it would likely require a much longer time-on the order of weeks (Smith et al., 2004a,b; Wysocki and Ladich, 2005). Furthermore, the possibility that fish become accustomed to the acoustic stress does not exclude the presence of any negative impacts (Bejder et al., 2009). In fact, although fish get used to stress, it is possible to find effects on essential functions, such as the distribution and organization of the group, with consequences at physiological (Anderson et al., 2011; Filiciotto et al., 2013) and auditory levels (Vasconcelos et al., 2007).

Although it has not been directly demonstrated, the behavioural changes observed could have consequences on the survival, reproduction, foraging, and growth of the species and the time of surveillance of the offspring, which could also be adversely impacted (Picciulin et al., 2010; Blom et al., 2019).

In this study, we characterized the sounds referring to the pressure unit $(1 \mu \mathrm{Pa})$, but many fish can also detect particle displacement, particularly at frequencies below a few hundred hertz (Popper and Hawkins, 2018).

Although we are aware of the importance of describing sounds in terms of particle motion as well as sound pressure, when investigating the effects of sounds on fish (Popper and Hawkins, 2019), we could not directly obtain such measurements. On the other hand, measurements of particle displacement in three dimensions in a small tank are heavily affected by the presence of reflecting walls, bottom and water surface, and their usefulness becomes restricted (Ceraulo et al., 2016). The results of our study are based on comparisons between control and acoustic groups and not between the different acoustic stimuli. In light of these 
considerations, the particle motion measurements became of secondary importance. Laboratory measurements can produce different results when compared to equivalent data obtained in the natural environment. For example, fish in the wild have been shown to react more strongly to acoustic stress compared to captive fish (Benhaïm et al., 2012; Lepage et al., 2000). Unknown environmental conditions in the field can also influence behaviour of wild fish (Brewer, 2000). This makes it difficult to obtain controlled measurements in the field. So, although field measurements are very important, our study shows that laboratory experiments benefit from the ability to carry out behavioural experiments in a reliable and controlled manner; the costs are also much less prohibitive compared to field surveys (Bruintjes et al., 2017).

Although in our work some variables in the behaviour analysis did not show significant differences (e.g., $500 \mathrm{~Hz}$ on motility and $125 \mathrm{~Hz}$ on swimming height), this does not necessarily indicate the absence of an effect since individuals can respond to stress with different strategies which may not have been apparent simply by visual observation (Koolhaas et al., 2011; Silva et al., 2010). Previous studies have demonstrated that human generated noise can cause stress in fish leading to physiological changes in levels of heat shock proteins, cortisol, glucose, protein concentration, and lactate in plasma and tissue (Santulli et al., 1999; Buscaino et al., 2010; Celi et al., 2016; Vazzana et al., 2017; Anderson et al., 2011; Smith et al., 2004a; Wysocki et al., 2006). Although probably a hormonal variation would have been found following acoustic stress (Anderson et al., 2011; Santulli et al., 1999; Smith et al., 2004a; Wysocki et al., 2006), an evaluation of the physiological effects was not possible during the present study, and further investigations in this area are warranted.

\section{CONCLUSIONS}

For the first time, our study compared the effects of different acoustic frequencies (within the range $63-1000 \mathrm{~Hz}$ ) on the behavioural responses of juvenile individuals of $S$. aurata in controlled laboratory experiments. Our results showed that the largest responses occurred at the two lowest tested frequencies, $63 \mathrm{~Hz}$ and $125 \mathrm{~Hz}$. This finding is in accordance with the MSFD (Directive 2008/56/EC), which recognises that sound at these frequencies is a potential threat for marine organisms, particularly considering it can travel for long distances in deep water. The observed changes in the fish dispersion, motility, and swimming depth during the acoustic exposure trials could lead to negative consequences for fish in the wild by restricting their normal behaviours such as food acquisition, migration, reproduction, and intraspecific communication. This becomes more important when considering that the tested fish were juveniles, which are more susceptible to reductions in survival rates than adults.

\section{ACKNOWLEDGMENTS}

This study was conducted in the framework of the Ph.D. program in the Mediterranean Biodiversity XXXII cycle (International) of the University of Palermo. I.P.-A., M.B.-C. and V.E. acknowledge the financial support of the European Comission-Project No. 11.0661/2018794607/ SUB/ENV.C2, risk-based approaches to good environmental status (RAGES). The other founding support comes from the Ph.D. Innovative with Industrial Characterization Programma Operativo Nazionale (PON) 2014-2020 and the projects bilateral Research laboratory on marine and maritime Science Italy-Argentina (CAIMAR) Joint Laboratory Italy-Argentina (Laboratori Congiunti Bilaterali Internazionali of the Italian National Reseach Council, 2017-2019).

Anderson, P. A., Berzins, I. K., Fogarty, F., Hamlin, H. J., and Guillette, L. J., Jr. (2011). "Sound, stress, and seahorses: The consequences of a noisy environment to animal health," Aquaculture 311, 129-138.

Bejder, L., Samuels, A., Whitehead, H., Finn, H., and Allen, S. (2009). "Impact assessment research: Use and misuse of habituation, sensitisation and tolerance in describing wildlife responses to anthropogenic stimuli," Mar. Ecol. Prog. Ser. 395, 177-185.

Benhaïm, D., Péan, S., Lucas, G., Blanc, N., Chatain, B., and Bégout, M.-L. (2012). "Early life behavioural differences in wild caught and domesticated seabass (Dicentrarchus labrax)," Appl. Anim. Behav. Sci. 141, 79-90.

Blaxter, J. H. S., Gray, J. A. B., and Denton, E. J. (1981). "Sound and startle responses in herring shoals," J. Mar. Biol. Assoc. U. K. 61, 851-869.

Blom, E. L., Kvarnemo, C., Dekhla, I., Schöld, S., Andersson, M. H., Svensson, O., and Amorim, M. C. P. (2019). "Continuous but not intermittent noise has a negative impact on mating success in a marine fish with paternal care," Sci. Rep. 9(1), 5494.

Borsani, J., Faulkner, R., and Merchant, N. (2015). "Impacts of noise and use of propagation models to predict the recipient side of noise," Report prepared under contract ENV.D.2/FRA/2012/0025 for the European Commission, Centre for Environment, Fisheries and Aquaculture Science, $\mathrm{UK}$

Brewer, M. (2000). "Research design and issues of validity," in Handbook of Research Methods in Social and Personality Psychology, edited by H. Reis and C. Judd (Cambridge University Press, Cambridge, UK), pp. $3-16$.

Bruintjes, R., Harding, H., Bunce, T., Birch, F., Lister, J., Spiga, I., Benson, T., Rossington, S., Jones, D., Tyler, C., Radford, A., and Simpson, S. (2017). "Shipbuilding docks as experimental systems for realistic assessments of anthropogenic stressors on marine organisms," Bioscience 67(9), 853-859.

Buscaino, G., Filiciotto, F., Buffa, G., Bellante, A., Stefano, V. D., Assenza, A., Fazio, F., Caola, G., and Mazzola, S. (2010). "Impact of an acoustic stimulus on the motility and blood parameters of European sea bass (Dicentrarchus labrax L.) and gilthead sea bream (Sparus aurata L.)," Mar. Environ. Res. 69, 136-142.

Cachat, J., Stewart, A., Grossman, L., Gaikwad, S., Kadri, F., Chung, K. M., Wu, N., Wong, K., Roy, S., Suciu, C., Goodspeed, J., Elegante, M., Bartels, B., Elkhayat, S., Tien, D., Tan, J., Denmark, A., Gilder, T., Kyzar, E., Dileo, J., Frank, K., Chang, K., Utterback, E., Hart, P., and Kalueff, A. V. (2010). "Measuring behavioral and endocrine responses to novelty stress in adult zebrafish," Nat. Protoc. 5, 1786-1799.

Carroll, A. G., Przeslawski, R., Duncan, A., Gunning, M., and Bruce, B. (2017). "A critical review of the potential impacts of marine seismic surveys on fish and invertebrates," Mar. Poll. Bull. 114, 9-24.

Casper, B. M., Smith, M. E., Halvorsen, M. B., Sun, H., Carlson, T. J., and Popper, A. N. (2013). "Effects of exposure to pile driving sounds on fish inner ear tissues," Comp. Biochem. Physiol. Part A Mol. Integr. Physiol. 166, 352-360.

Castellote, M., Clark, C. W., and Lammers, M. O. (2012). "Acoustic and behavioural changes by fin whales (Balaenoptera physalus) in response to shipping and airgun noise," Biol. Conserv. 147, 115-122.

Celi, M., Filiciotto, F., Maricchiolo, G., Genovese, L., Quinci, E. M., Maccarrone, V., Mazzola, S., Vazzana, M., and Buscaino, G. (2016). "Vessel noise pollution as a human threat to fish: Assessment of the stress 
response in gilthead sea bream (Sparus aurata, Linnaeus 1758)," Fish Physiol. Biochem. 42, 631-641.

Ceraulo, M., Bruintjes, R., Benson, T., Rossington, K., Farina, A., and Buscaino, G. (2016). "Relationships of underwater sound pressure and particle velocity during pile driving in a flooded dock," Proc. Mtgs. Acoust. 27, 040007.

Codarin, A., Wysocki, L. E., Ladich, F., and Picciulin, M. (2009). "Effects of ambient and boat noise on hearing and communication in three fish species living in a marine protected area (Miramare, Italy)," Mar. Pollut. Bull. 58, 1880-1887.

Cox, T. M., Ragen, T. J., Read, A. J., Vos, E., Baird, R. W., Balcomb, K., Barlow, J., Caldwell, J., Cranford, T., Crum, L., D’Amico, A., D’Spain, G., Fernández, A., Finneran, J., Gentry, R., Gerth, W., Gulland, F., Hildebrand, J., Houser, D., Hullar, T., Jepson, P. D., Ketten, D., MacLeod, C. D., Miller, P., Moore, S., Mountain, D., Palka, D., Ponganis, P., Rommel, S., Rowles, T., Taylor, B., Tyack, P., Wartzok, D., Gisiner, R., Mead, J., and Benner, L. (2006). "Understanding the impacts of anthropogenic sound on beaked whales," J. Cetacean Res. Manag. 7, $177-187$.

Day, R. D., McCauley, R. M., Fitzgibbon, Q. P., Hartmann, K., and Semmens, J. M. (2016). "Assessing the impact of marine seismic surveys on southeast Australian scallop and lobster fisheries," University of Tasmania, Hobart, October.

Dekeling, R. P. A., Tasker, M. L., Van der Graaf, A. J., Ainslie, M. A., Andersson, M. H., André, M., Borsani, J. F., Brensing, K., Castellote, M., Cronin, D., Dalen, J., Folegot, T., Leaper, R., Pajala, J., Redman, P., Robinson, S. P., Sigray, P., Sutton, G., Thomsen, F., Werner, S., Wittekind, D., and Young, J. V. (2014). "Monitoring guidance for underwater noise in European seas, Part II: Monitoring guidance specifications, JRC Scientific and Policy Report EUR 26555 EN," Publications Office of the European Union, Luxembourg.

De Quirós, J. B., Fernandez, A., Baird, R. W., Brownell, R. L., Aguilar de Soto, N., Allen, D., Arbelo, M., Arregui, M., Costidis, A., Fahlman, A., Frantzis, A., Gulland, M., Iñíguez, F. M. D., Johnson, M., Komnenou, A., Koopman, H., Pabst, D. A., Roe, W. D., Sierra, E., Tejedor, M., and Schorr, G. (2019). "Advances in research on the impacts of antisubmarine sonar on beaked whales," Proc. R. Soc. B 286, 20182533.

Doksæter, L., Handegard, N. O., Godø, O. R., Kvadsheim, P. H., and Nordlund, N. (2012). "Behavior of captive herring exposed to naval sonar transmissions (1.0-1.6 kHz) throughout a yearly cycle," J. Acoust. Soc. Am. 131, 1632-1642.

Domjan, M. (2010). The Principles of Learning and Behaviour, 6th ed. (Wadsworth, Cengage Learning, Belmont, CA).

Fakan, E. P., and McCormick, M. I. (2019). "Boat noise affects the early life history of two damselfishes," Mar. Poll. Bull. 141, 493-500.

Ferrari, M. C. O., McCormick, M. I., Meekan, M. G., Simpson, S. D., Nedelec, S. L., and Chivers, D. P. (2018). "School is out on noisy reefs: The effect of boat noise on predator learning and survival of juvenile coral reef fishes," Proc. R. Soc. B 285, 20180033.

Fewtrell, J. L., and McCauley, R. D. (2012). "Impact of air gun noise on the behaviour of marine fish and squid," Mar. Pollut. Bull. 64, 984-993.

Filiciotto, F., Giacalone, V. M., Fazio, F., Buffa, G., Piccione, G., Maccarrone, V., Di Stefano, V., Mazzola, S., and Buscaino, G. (2013). "Effects of acoustic environment on gilthead sea bream (Sparus aurata): Sea and onshore aquaculture background noise," Aquaculture. 414-415, 36-45.

Filiciotto, F., Vazzana, M., Celi, M., Maccarrone, V., Ceraulo, M., Buffa, G., Di Stefano, V., Mazzola, S., and Buscaino, G. (2014). "Behavioural and biochemical stress responses of Palinurus elephas after exposure to boat noise pollution in tank," Mar. Poll. Bull. 84,104-114.

Fine, M. L., King, T. L., Ali, H., Sidker, N., and Cameron, T. M. (2016). "Wall structure and material properties cause viscous damping of swim bladder sounds in the oyster toadfish Opsanus tau," Proc. R. Soc. London B 283, 1-9.

Gerlotto, F., and Fréon, P. (1992). "Some elements on vertical avoidance of fish schools to a vessel during acoustic surveys," Fish. Res. 14, 251-259.

Gordon, J., Gillespie, D., Potter, J., Frantzis, A., Simmonds, M. P., Swift, R., and Thompson, D. (2003). "A review of the effects of seismic surveys on marine mammals," Mar. Technol. Soc. J. 37, 16-34.

Handegard, N. O., Michalsen, K., and Tjøstheim, D. (2003). "Avoidance behaviour in cod (Gadus morhua) to a bottom-trawling vessel," Aquat. Living Resour. 16, 265-270.
Hawkins, A., Knudsen, F. R., Davenport, J., McAllen, R., Bloomfield, H. J., Schilt, C., and Johnson, P. (2012). "Grazing by sprat schools upon zooplankton within an enclosed marine lake," J. Exp. Mar. Biol. Ecol. 411, 59-65.

Hawkins, A. D., Pembroke, A. E., and Popper, A. N. (2015). "Information gaps in understanding the effects of noise on fishes and invertebrates," Rev. Fish Biol. Fish. 25, 39-64.

Hawkins, A. D., Roberts, L., and Cheesman, S. (2014). "Responses of freeliving coastal pelagic fish to impulsive sounds," J. Acoust. Soc. Am. 135, 3101-3116.

Holles, S., Simpson, S. D., Radford, A. N., Berten, L., and Lecchini, D. (2013). "Boat noise disrupts orientation behaviour in a coral reef fish," Mar. Ecol. Prog. Ser. 485, 295-300.

Holmes, J. L., McWilliam, J., Ferrari, M. C. O., and McCormick, M. I. (2017). "Juvenile damselfish are affect but desensitize to small motor boat noise,” J. Exp. Mar. Biol. Ecol. 494, 63-68.

Israeli-Weinstein, D., and Kimmel, E. (1998). "Behavioral response of carp (Cyprinus carpio) to ammonia stress," Aquaculture 165, 81-93.

Kastelein, R. A., van der Heul, S., Verboom, W. C., Jennings, N., van der Veen, J., and de Haan, D. (2008). "Startle response of captive North Sea fish species to underwater tones between 0.1 and $64 \mathrm{kHz}$," Mar. Environ. Res. 65, 369-377.

Ketten, D. R., Lien, J., and Todd, S. (1993). "Blast injury in humpback whale ears: Evidence and implications," J. Acoust. Soc. Am. 94(3), 1849-1850.

Koolhaas, J. M., Bartolomucci, A., Buwalda, B., de Boer, S. F., Flügge, G., Korte, S. M., Meerlo, P., Murison, R., Olivier, B., Palanza, P., Sgoifo, A., Steimer, T., Stiedl, O., van Dijk, G., Wöhr, M., and Fuchs, E. (2011). "Stress revisited: A critical evaluation of the stress concept," Neurosci. Biobehav. Rev. 35, 1291-1301.

Kunc, H. P., McLaughlin, K. E., and Schmidt, R. (2016). "Aquatic noise pollution: Implications for individuals, populations, and ecosystems," Proc. R. Soc. B Biol. Sci. 283, 20160839.

Kuwada, H., Masuda, R., Shiozawa, S., Kogane, T., Imaizumi, K., and Tsukamoto, K. (2000). "Effect of fish size, handling stresses and training procedure on the swimming behavior of hatchery-reared striped jack: Implications for stock enhancement," Aquaculture 185, 245-256.

Lecchini, D., Bertucci, F., Gache, C., Khalife, A., Besson, M., Roux, N., Berthe, C., Singh, S., Parmentier, E., Nugues, M. M., Brooker, R. M., Dixson, D. L., and Hédouin, L. (2018). "Boat noise prevents soundscape based habitat selection by coral planulae," Sci. Rep. 8, 9283.

Lepage, O., Øverli, Ø., Petersson, E., Järvi, T., and Winberg, S. (2000). "Differential stress coping in wild and domesticated sea trout," Brain Behav. Evol. 56, 259-268.

Lloris, D. (2005). "Sparus aurata," in A World Overview of Species of Interest to Fisheries, available at www.fao.org/figis/servlet/species? fid $=2384$. 3p, FIGIS Species Fact Sheets, Species Identification and Data Programme-SIDP, FAO-FIGIS (Last viewed 8 July 2005).

Luca, R. M., and Gerlai, R. (2012). "In search of optimal fear inducing stimuli: Differential behavioral responses to computer animated images in zebrafish,” Behav. Brain Res. 226, 66-76.

Lyamin, O. I., Korneva, S. M., Rozhnov, V. V., and Mukhametov, L. M. (2011). "Cardiorespiratory changes in beluga in response to acoustic noise," Dokl. Biol. Sci. 440, 257-258.

Martín López, L. M., Miller, P. J. O., Aguilar de Soto, N., and Johnson, M. (2015). "Gait switches in deep-diving beaked whales: Biomechanical strategies for longduration dives," J. Exp. Biol. 218, 1325-1338.

McCauley, R. D., Day, R. D., Swadling, K. M., Fitzgibbon, Q. P., Watson, R. A., and Semmens, J. M. (2017). "Widely used marine seismic survey air gun operations negatively impact zooplankton," Nat. Ecol. Evol. 1(7), 195.

McCauley, R. D., Fewtrell, J., Duncan, A. J., Jenner, C., Jenner, M.-N., Penrose, J. D., Prince, R. I. T., Adhitya, A., Murdoch, J., and McCabe, K. (2000). "Marine seismic surveys-A study of environmental implications," APPEA J. 40, 692-706.

McCauley, R. D., Fewtrell, J., and Popper, A. N. (2003). "High intensity anthropogenic sound damages fish ears," J. Acoust. Soc. Am. 113, 638-642. McCormick, M. I., and Lönnstedt, O. M. (2013). "Degrading habitats and the effect of topographic complexity on risk assessment," Ecol. Evol. 3, 4221-4229.

McCormick, M. I., Makey, L., and Dufour, V. (2002). "Comparative study of metamorphosis in tropical reef fishes," Mar. Biol. 141, 841-853. 
McCormick, S. D., Shrimpton, J. M., Carey, J. B., O’Dea, M. F., Sloan, K. E., Moriyama, S., and Björnssonc, B. Th. (1998). "Repeated acute stress reduces growth rate of Atlantic salmon parr and alters plasma levels of growth hormone, insulin-like growth factor I and cortisol," Aquaculture $168,221-235$.

Mesa, M. G. (1994). "Effects of multiple acute stressors on the predator avoidance ability and physiology of juvenile chinook salmon," Trans. Am. Fish. Soc. 123, 786-793.

Mueller-Blenkle, C., McGregor, P. K., Gill, A. B., Andersson, M. H., Metcalfe, J., Bendall, V., Sigray, P., Wood, D. T., and Thomsen, F. (2010). "Effects of pile-driving noise on the behaviour of marine fish," Tech. Report, COWRIE Ref: Fish 06-08.

Munday, P. L., Dixson, D. L., McCormick, M. I., Meekan, M. G., Ferrari, M. C. O., and Chivers, D. P. (2010). "Replenishment of fish populations is threatened by ocean acidification," Proc. Natl. Acad. Sci. U.S.A. 107, 12930-12934.

Nedelec, S. L., Mills, S. C., Lecchini, D., Nedelec, B., Simpson, S. D., and Radford, A. N. (2016). "Repeated exposure to noise increases tolerance in a coral reef fish," Environ. Pollut. 216, 428-436.

Nedelec, S. L., Radford, A. N., Pearl, L., Nedelec, B., McCormick, M. I., Meekan, M. G., and Simpson, S. D. (2017). "Motorboat noise impacts parental behaviour and offspring survival in a reef fish," Proc. R. Soc. B 284, 20170143.

Nedelec, S. L., Radford, A. N., Simpson, S. D., Nedelec, B., Lecchini, D., and Mills, S. C. (2014). "Anthropogenic noise playback impairs embryonic development and increases mortality in a marine invertebrate," Sci. Rep. 4, 5891.

Nedelec, S. L., Simpson, S. D., Morley, E. L., Nedelec, B., and Radford, A. N. (2015). "Impacts of regular and random noise on the behaviour, growth and development of larval Atlantic cod (Gadusmorhua)," Proc. R. Soc. B 282, 20151943.

Nelson, D., and Johnson, R. (1972). "Acoustic attraction of Pacific reef sharks: Effect of pulse intermittency and variability," Comp. Biochem. Physiol. Part A Physiol. 42, 85-95.

Neo, Y. Y., Hubert, J., Bolle, L. J., Winter, H. V., and Slabbekoorn, H. (2018). "European seabass respond more strongly to noise exposure at night and habituate over repeated trials of sound exposure," Environ. Pollut. 239, 367-374.

Neo, Y. Y., Hubert, J., Bolle, L., Winter, H. V., ten Cate, C., and Slabbekoorn, H. (2016). "Sound exposure changes European seabass behaviour in a large outdoor floating pen: Effects of temporal structure and a ramp-up procedure," Environ. Pollut. 214, 26-34.

Neo, Y. Y., Seitz, J., Kastelein, R. A., Winter, H. V., ten Cate, C., and Slabbekoorn, H. (2014). "Temporal structure of sound affects behavioural recovery from noise impact in European seabass," Biol. Conserv. 178, 65-73.

Neo, Y. Y., Ufkes, E., Kastelein, R. A., Winter, H. V., ten Cate, C., and Slabbekoorn, H. (2015). "Impulsive sounds change European seabass swimming patterns: Influence of pulse repetition interval," Mar. Pollut. Bull. 97, 111-117.

Nilsson, G. E., Ostlund-Nilsson, S., Penfold, R., and Grutter, A. S. (2007). "From record performance to hypoxia tolerance: Respiratory transition in damselfish larvae settling on a coral reef," Proc. R. Soc. B 274, 79-85.

Parmentier, E., and Fine M. L. (2016). "Fish sound production: Insights," in Vertebrate Sound Production and Acoustic Communication, edited by R. A. Suthers and T. Fitch (Springer, New York), pp. 19-49.

Pearson, W. H., Skalski, J. R., and Malme, C. I. (1992). "Effects of sounds from a geophysical survey device on behavior of captive rockfish (Sebastes spp.)," Can. J. Fish. Aquat. Sci. 49, 1343-1356.

Picciulin, M., Sebastianutto, L., Codarin, A., Farina, A., and Ferrero, E. A. (2010). "In situ behavioural responses to boat noise exposure of Gobiuscruentatus (Gmelin, 1789; fam. Gobiidae) and Chromischromis (Linnaeus, 1758; fam. Pomacentridae) living in a Marine protected area," J. Exp. Mar. Biol. Ecol. 386, 125-132.

Popper, A. N., Fay, R. R., Platt, C., and Sand, O. (2003). "Sound detection mechanism and capabilities of teleost fishes," in Sensory Processing in Aquatic Environments, edited by S. P. Collin and N. J. Marshall (Springer, New York), pp. 3-38.

Popper, A. N., and Hawkins, A. D. (2018). "The importance of particle motion to fishes and invertebrates," J. Acoust. Soc. Am. 143, 470-486.

Popper, A. N., and Hawkins, A. D. (2019). "An overview of fish bioacoustics and the impacts of anthropogenic sounds on fishes," J. Fish Biol. 94, 692-713.
Purser, J., and Radford, A. N. (2011). "Acoustic noise induces attention shifts and reduces foraging performance in three-spined sticklebacks (Gasterosteus aculeatus)," PLoS One 6, e17478.

Rankin, C. H., Abrams, T., Barry, R. J., Bhatnagar, S., Clayton, D. F., Colombo, J., Coppola, G., Geyer, M. A., Glanzman, D. L., Marsland, S., McSweeney, F. K., Wilson, D. A., Wu, C.-F., and Thompson, R. F. (2009). "Habituation revisited: An updated and revised description of the behavioral characteristics of habituation," Neurobiol. Learn. Memory. 92, 135-138.

Rankin, C. H., and Broster, B. S. (1992). "Factors affecting habituation and recovery from habituation in the nematode Caenorhabditis elegans," Behav. Neurosci. 106, 239-249.

Rolland, R. M., Parks, S. E., Hunt, K. E., Castellote, M., Corkeron, P. J., Nowacek, D. P., and Kraus, S. D. (2012). "Evidence that ship noise increases stress in right whales," Proc. R. Soc. B: Biolog. Sci. 279(1737), 2363-2368.

Romano, T. A., Keogh, M. J., Kelly, C., Feng, P., Berk, L., Schlundt, C. E., Carder, D. A., and Finneran, J. J. (2004). "Anthropogenic sound and marine mammal health: Measures of the nervous and immune systems before and after intense sound exposure," Can. J. Fish. Aquat. Sci. 61, $1124-1134$.

Salas, A. K., Wilson, P. S., and Fuiman, L. A. (2019). "Ontogenetic change in predicted acoustic pressure sensitivity in larval red drum (Sciaenops ocellatus)," J. Exp. Biol. 222, 1-12.

Santulli, A., Modica, A., Messina, C., Ceffa, L., Curatolo, A., Rivas, G., Fabi, G., and D'Amelio, V. (1999). "Biochemical responses of European sea bass (Dicentrarchus labrax L.) to the stress induced by off shore experimental seismic prospecting," Mar. Pollut. Bull. 38, 1105-1114.

Sarà, G., Dean, J. M., D'Amato, D., Buscaino, D., Oliveri, A., Genovese, S., Ferro, S., Buffa, G., Lo Martire, M., and Mazzola, S. (2007). "Effect of boat noise on the behaviour of bluefin tuna Thunnus thynnus in the mediterranean sea," Mar. Ecol. Prog. Ser. 331, 243-253.

Shi, W., Han, Y., Guan, X., Rong, J., Du, X., Zha, S., Tang, Y., and Liu, G. (2019). "Anthropogenic noise aggravates the toxicity of cadmium on some physiological characteristics of the blood clam Tegillarca granosa," Front. Physiol. 10, 377.

Silva, P. I. M., Martins, C. I. M., Engrola, S., Marino, G., Øverli, Ø., and Conceicao, L. E. C. (2010). "Individual differences in cortisol levels and behaviour of Senegalese sole (Solea senegalensis) juveniles: Evidence for coping styles," Appl. Anim. Behav. Sci. 124, 75-81.

Simpson, S. D., Meekan, M. G., Larsen, N. J., McCauley, R. D., and Jeffs, A. (2010). "Behavioral plasticity in larval reef fish: Orientation is influenced by recent acoustic experiences," Behav. Ecol. 21(5), 1098-1105.

Simpson, S. D., Radford, A. N., Nedelec, S. L., Ferrari, M. C., Chivers, D. P., McCormick, M. I., and Meekan, M. G. (2016). "Anthropogenic noise increases fish mortality by predation," Nat. Commun. 7, 10544.

Skilbrei, O., and Holst, J. (2009). "Vertical movements of 'escaped' farmed Atlantic salmon (Salmo salar L.) - A simulation study in a western Norwegian fjord,” ICES J. Mar. Sci. 66, 278-288.

Slabbekoorn, H., Bouton, N., van Opzeeland, I., Coers, A., ten Cate, C., and Popper, A. N. (2010). "A noisy spring: The impact of globally rising underwater sound levels on fish," Trends Ecol. Evol. 25, 419-427.

Slotte, A., Hansen, K., Dalen, J., and Ona, E. (2004). "Acoustic mapping of pelagic fish distribution and abundance in relation to a seismic shooting area off the Norwegian west coast," Fish. Res. 67, 143-150.

Smith, M. E., Kane, A. S., and Popper, A. N. (2004a). "Noise-induced stress response and hearing loss in goldfish (Carassius auratus)," J. Exp. Biol. 207(3), 427-435.

Smith, M. E., Kane, A. S., and Popper, A. N. (2004b). "Acoustical stress and hearing sensitivity in fishes: Does the linear threshold shift hypothesis hold water?," J. Exp. Biol. 207, 3591-3602.

Sogard, S. M. (1997). "Size-selective mortality in the juvenile stage of teleost fishes: A review," Bull. Mar. Sci. 60, 1129-1157.

Solé, M., Lenoir, M., Durfort, M., López-Bejar, M., Lombarte, A., and André, M. (2013b). "Ultrastructural damage of Loligo vulgaris and Illexcoindetii statocysts after low frequency sound exposure," PLoS One 8(10), e78825.

Solé, M., Lenoir, M., Durfort, M., López-Bejar, M., Lombarte, A., van der Schaar, M., and André, M. (2013a). "Does exposure to noise from human activities compromise sensory information from cephalopod statocysts?," Deep Sea Res., Part II 95, 160-181.

Spiga, I., Aldreda, N., and Caldwella, G. S. (2017). "Anthropogenic noise compromises the anti-predator behaviour of the European seabass, Dicentrarchus labrax (L.)," Mar. Poll. Bull. 122, 297-305. 
Thorpe, W. H. (1963). Learning and Instinct in Animals (Methuen, London), $61 \mathrm{pp}$.

Van Parijs, S. M., and Corkeron, P. J. (2001). "Boat traffic affects the acoustic behaviour of Pacific humpback dolphins, Sousa chinensis," J. Mar. Biol. Assoc. U. K. 81, 533-538.

Vasconcelos, R. O., Amorim, M. C. P., and Ladich, F. (2007). "Effects of ship noise on the detectability of communication signals in the Lusitanian toadfish," J. Exp. Biol. 210, 2104-2112.

Vazzana, M., Celi, M., Arizza, V., Calandra, G., Buscaino, G., Ferrantelli, V., Bracciali, C., and Sará, G. (2017). "Noise elicits haematological stress parameters in Mediterranean damselfish (Chromis chromis, perciformes): A mesocosm study," Fish Shellfish. Immun. 62, 147-152.

Vazzana, M., Celi, M., Genovese, L., Corrias, V., Quinci, E. M., De Vincenzi, G., Maccarrone, V., Cammilleri, G., Mazzola, S., Buscaino, G., and Filiciotto, F. (2016). "Are mussels able to distinguish underwater sounds? Assessment of the reactions of Mytilus galloprovincialis after exposure to lab-generated acoustic signals," Compar. Bioch. Phys, A 201, 61-70.

Vazzana, M., Ceraulo, M., Mauro, M., Papale, E., Dioguardi, M., Mazzola, S., Arizza, V., Chiaramonte, M., and Buscaino, G. (2020b). "Effects of acoustic stimulation on biochemical parameters in the digestive gland of Mediterranean mussel Mytilus galloprovincialis (Lamark, 1819)," J. Acoust. Soc. Am. 147(4), 2414-2422.

Vazzana, M., Mauro, M., Ceraulo, M., Dioguardi, M., Papale, E., Mazzola, S., Arizza, V., Beltrame, F., Ingugli, L., and Buscaino, G. (2020a). "Underwater high frequency noise: Biological responses in sea urchin
Arbacia lixula (Linnaeus, 1758)," Comp. Bioch. Phys-Part A: Mol. Integr. Phys. 242,110650.

Wardle, C. S., Carter, T. J., Urquhart, G. G., Johnstone, A. D. F., Ziolkowski, A. M., Hampson, G., and Mackie, D. (2001). "Effects of seismic air guns on marine fish," Cont. Shelf Res. 21, 1005-1027.

Weilgart, L. S. (2007). "The impacts of anthropogenic ocean noise on cetaceans and implications for management," Can. J. Zool. 85, 1091-1116.

Wilson, B., and Dill, L. M. (2002). "Pacific herring respond to simulated odontocete echolocation sounds," Can. J. Fish. Aquat. Sci. 59, $542-553$.

Wood, S. N., Pya, N., and Säfken, B. (2016). "Smoothing parameter and model selection for general smooth models," J. Am. Stat. Assoc. 111, $1548-1563$.

Woodley, C. M., and Peterson, M. S. (2003). "Measuring responses to simulated predation threat using behavioral and physiological metrics: The role of aquatic vegetation," Oecologia 136, 155-160.

Wysocki, L. E., Dittami, J. P., and Ladich, F. (2006). "Ship noise and cortisol secretion in European freshwater fishes," Bio. Conserv. 128, 501-508.

Wysocki, L. E., and Ladich, F. (2005). "Effects of noise exposure on click detection and the temporal resolution ability of the goldfish auditory system," Hear. Res. 201, 27-36.

Zhou, W., Huang, X., and Xu, X. (2018). "Changes of movement behavior and HSP70 gene expression in the hemocytes of the mud crab (Scylla paramamosain) in response to acoustic stimulation," Mar. Fresh. Beh. Phys. 51, 3-14. 